\title{
KREDIBILITAS DAN OTENTISITAS GURU KEWIRAUSAHAAN TERHADAP KARAKTER KEWIRAUSAHAAN SISWA SMK NEGERI DI SURABAYA
}

\author{
Muhammad Abdul Ghofur*
}

ABSTRACT

Entrepreneurship in vocational education in Surabaya is still lack of attention. Many educators are paying less attention to character growth and entrepreneurial behavior. Their orientation is, generally only on preparing the workforce. To that end, the solution needs to be sought, how education can serve to turn people into human character or behavior and entrepreneurship. The research, therefore, aims at obtaining an explanation of the influence of teachers' entrepreneurship credibility and authenticity on the students' entrepreneurial character in SMK Negeri Surabaya. This research is a verification. The technique used to test the hypothesis is structural equation model (SEM). The results provide an explanation that the variable credibility and authenticity of entrepreneurship teachers have simultaneous significant effect on students' entrepreneurial character in SMK Negeri Surabaya, whereas the two variables are partially proven to be unsignificant.

Keywords: Credibility, Authenticity, Character Entrepreneurship.

\section{PENDAHULUAN}

$\mathrm{K}$ emampuan dunia pendidikan Indonesia dalam menjawab tantangan kebutuhan output yang mempunyai kapabilitas dan kompetensi yang sesuai dengan kebutuhan riil dalam menunjang pembangunan masih jauh dari harapan. Menurut survei yang dilakukan UNESCO pada tahun 2011, hanya enam persen output pendidikan nasional yang mampu bersaing secara global (Jawa Pos, 22-3-2012). Salah satu program pendidikan nasional adalah dengan meningkatkan kualitas pendidikan Sekolah Menengah Kejuruan (SMK). Perbaikan kualitas pembelajaran ini meliputi berbagai aspek, baik sarana dan prasarana, perbaikan metode pembelajaran, perangkat pembelajaran maupun tenaga pengajar itu sendiri.

Lulusan SMK yang berkualitas diharapkan mampu menjawab kebutuhan tenaga kerja di lapangan. Pembentukan karakter kewirausahaan (enterpreneurship) siswa sudah saatnya mendapatkan prioritas dalam pembelajaran di SMK sebagai bekal bagi para alumni selepas lulus sekolah. Selain mampu mengatasi pengangguran, kewirausahaan juga diyakini mampu memperkokoh ketahanan ekonomi negara melalui sektor Usaha Kecil Menengah (UKM) yang terbukti sanggup bertahan ketika krisis. Pada sisi kebijakan pendidikan di Indonesia pembentukan karakter kewirausaan sangat relevan dengan tujuan dan fungsi utama pendidikan karakter. Bahkan pendidikan karakter di Indonesia saat ini ditempatkan sebagai landasan untuk mewujudkan visi pembangunan nasional, hal ini tercermin dalam Pasal 3 Undang-undang No. 20 Tahun 2003 tentang Sistem Pen-

*) Universitas Negeri Surabaya 
didikan Nasional.

Terkait dengan upaya peningkatan kualitas lulusan dan pembangunan karakter kewirausahaan siswa, tidak ada salahnya kalau kita bercermin pada keberhasilan Finlandia dalam membangun kualitas pendidikannya. Finlandia dengan ibu kota Helsinki adalah salah satu negara dengan kualitas pendidikan terbaik di dunia (Sahlberg, 2010:6). Kunci sukses Finlandia terletak pada kualitas guru. Guru di Finlandia adalah guru terbaik dengan pelatihan terbaik juga. Profesi guru sendiri adalah profesi yang sangat dihargai.

Salah satu komponen penting dalam pembelajaran di mata siswa adalah bagaimana siswa memahami gurunya, baik sebagai mitra dalam belajar maupun sebagai otoritas. Siswa membutuhkan keyakinan bahwa guru mereka mengajarkan sesuatu dan memiliki sesuatu yang berguna serta penting untuk diajarkan, mereka juga ingin bisa mempercayai dan mengandalkan guru mereka. Seorang guru dianggap efektif karena ia mampu menggabungkan elemen-elemen penting dalam pembelajaran serta memiliki sesuatu yang penting untuk diajarkan atau ditunjukkan kepada siswa secara terbuka dan jujur. Siswa tidak mengukur efektivitas guru hanya dalam hal metode atau teknik tertentu yang digunakan.

Banyak pendekatan yang digunakan dalam berbagai penelitian untuk meneliti efektifitas seorang guru dalam mengajar diantaranya adalah gaya mengajar, kepribadian, struktur budaya, suku bangsa, usia, kelas sosial, gender, pengalaman sebelumnya dengan subjek, kesiapan untuk belajar, maupun nilai-nilai organisasi, namun semua faktor tersebut dan cenderung membuat generalisasi hambar dan tidak akurat (Brookfield, 2006:55-56). Hal ini sangat masuk akal dalam pandangan konstrutivistik dimana pembelajar mengkonstruksi realitasnya sendiri atau paling tidak menafsirkannya berdasarkan pada persepsipersepsi pengalaman mereka (Good dan Brophy dalam Smith dkk. 2009:84).

Brookfield melakukan penelitian pada ribuan hal-hal penting dalam kuesioner yang diberikan siswa dalam berbagai penelitian dan berbagai disiplin ilmu dan lokasi geografis yang mewakili keragaman dalam hal faktor-faktor yang diidentifikasi di atas, muncul dua kelompok umum karakteristik guru. Kedua kelompok ini memiliki validitas internal yang cukup untuk dipertimbangkan sebagai panduan dalam aplikasi penelitian. Kedua kelompok adalah kredibilitas (credibility) dan otentisitas (authenticity).

Kredibilitas merupakan persepsi siswa bahwa guru memiliki sesuatu yang penting untuk dimiliki dalam melaksanakan proses pembelajaran. Sedangkan "sesuatu" itu adalah keterampilan, pengetahuan, wawasan, kebijaksanaan, dan informasi sehingga siswa merasa mendapat manfaat yang berarti dari proses pembelajaran (Brookfield, 2006:56). McCroskey mendefinisikan kredibilitas guru sebagai "sikap yang dirasakan siswa dimana guru tersebut dipandang sebagai sumber yang dipercaya" (1998:80). Kredibilitas seorang guru ditentukan oleh persepsi orang lain. Di ruang kelas itu, persepsi siswa menentukan kredibilitas guru.

Otentisitas merupakan persepsi siswa bahwa guru selalu terbuka dan jujur dalam usahanya untuk membantu siswa belajar. Dia dipandang sebagai manusia yang penuh gairah, antusiasme, lemah lembut, dan pengertian, bukan sebagai seseorang yang bersembunyi di balik perilaku peran belajar sesuai dengan predikatnya sebagai guru (Brookfield, 2006:55).

Cranton dan Carusetta menyatakan bahwa otentisitas adalah sebuah konsep multifaset yang mencakup setidaknya empat bagian: yang asli, menunjukkan konsistensi antara nilai-nilai dan tindakan, berhubungan dengan orang lain sedemikian rupa untuk mendorong keaslian mereka, dan selalu kritis (2004:7). Sedangkan Cranton dalam Cran- 
ton dan Carusetta (2004:7) sendiri mendefinisikan otentisitas sebagai ekspresi dari diri sejati dalam masyarakat dan disajikan suatu proses dimana guru dalam pendidikan tinggi mampu mengetahui diri mereka sendiri dan preferensi mereka dalam konteks sosial dari pekerjaan mereka.

Sebuah kelas yang dikelola oleh guru yang kredibilitasnya diakui namun dengan otentisitas yang rendah maka siswa biasanya merasa telah menghabiskan waktunya cukup dengan baik (karena keterampilan atau pengetahuan telah mampu dipelajari), tetapi mereka merasakan pengalaman dalam pembelajaran yang dingin, tidak ramah, atau bahkan merasa tertekan. Tanpa otentisitas guru sering dipandang sebagai sesuatu yang menakutkan. Siswa sering menganggap kesombongan atau dinginnya proses pembelajaran yang diterapkan guru dapat menghambat pembelajaran mereka. Hal ini menciptakan jarak antara guru dan siswa sehingga membuat sulit bagi peserta didik untuk meminta bantuan, mengajukan pertanyaan, mencari klarifikasi, dan sebagainya.

Di sisi lain, sebuah kelas dengan otentisitas guru yang kuat tetapi lemah pada kredibilitas dipandang sebagai tempat yang cukup menyenangkan tapi bukan tempat di mana banyak konsekuensi terjadi. Siswa sering berbicara tentang pembelajaran seperti ini seperti nilai yang mudah dan guru-guru yang menyenangkan. Guru dengan otentisitas suka dan sering berkonsultasi tentang segala macam masalah siswa secara pribadi. Siswa sering menginginkan guru dengan otentisitas yang baik, tetapi mereka biasanya tidak mementingkan bagaimana mereka belajar sesuatu yang sangat penting dari guru mereka.

Adanya kredibilitas guru menjamin penguasaan keterampilan maupun pengetahuan oleh siswa sesuai dengan tujuan pembelajaran, sedangkan otentisitas membuat proses pembelajaran menjadi menyenangkan dan siswa akan cenderung lebih antusias dalam mengikuti proses pembelajaran. Kedua kelompok karakteristik guru ini saling melengkapi, ketiadaan atau superioritas salah satu kelompok akan membuat proses pembelajaran menjadi tidak seimbang.

Peningkatan kredibilitas dan otentisitas guru dapat menjadi salah satu kunci keberhasilan pendidikan di Indonesia, khususnya dalam membentuk karakter kewirausahaan lulusan SMK. Ibarat sebuah opera dalam proses pembelajaran guru adalah seorang dirijen yang mengatur harmonisasi proses pembelajaran, sehingga proses pembelajaran berjalan optimal dan mencapai sasaran secara maksimal.

Peserta didiklah yang merasakan langsung bagaimana proses pembelajaran yang dibina oleh gurunya. Dengan demikian, kajian bagaimana kredibilitas dan otentisitas guru dalam proses pembelajaran dilihat dari sudut pandang siswa sangat penting untuk dilakukan, serta bagaimana perannya terhadap tingkat pencapaian pembelajaran siswa terutama dalam kaitannya dengan pembangunan karakter kewirausahaan siswa SMK di Surabaya. Kewirausahaan adalah salah satu mata pelajaran yang diajarkan di Sekolah Menengah Kejuruan (SMK). Mata pelajaran ini diajarkan mulai siswa kelas X sampai dengan kelas XII, hal ini menunjukkan begitu pentingnya penguasaan keterampilan dan karakter kewirausahaan bagi siswa SMK. Tujuan umum pembelajaran Kewirausahaan di SMK adalah untuk membekali siswa agar mampu hidup mandiri dan dapat menciptakan pekerjaan yang dapat menghasilkan pendapatan.

Pendidikan kewirausahaan di SMKN di Surabaya masih kurang memperoleh perhatian yang cukup memadai. Banyak pendidik yang kurang memperhatikan penumbuhan karakter dan perilaku wirausaha. Orientasi mereka, pada umumnya hanya pada menyiapkan tenaga kerja. Untuk itu, perlu dicari penyelesaiannya, bagaimana pendidikan dapat 
Tabel 1

Karakter Pokok dalam Pendidikan Kewirausahawan

\begin{tabular}{|c|c|}
\hline KARAKTER & DESKRIPSI \\
\hline 1. Mandiri & $\begin{array}{l}\text { Sikap dan prilaku yang tidak mudah tergantung pada orang lain } \\
\text { dalam menyelesaikan tugas-tugas }\end{array}$ \\
\hline 2. Kreatif & $\begin{array}{l}\text { Berpikir dan melakukan sesuatu untuk menghasilkan cara atau } \\
\text { hasil berbeda dari produk/jasa yang telah ada }\end{array}$ \\
\hline $\begin{array}{l}\text { 3. Berani men- } \\
\text { gambil Resiko }\end{array}$ & $\begin{array}{l}\text { Kemampuan seseorang untuk menyukai pekerjaan yang menant- } \\
\text { ang, berani dan mampu mengambil risiko kerja }\end{array}$ \\
\hline $\begin{array}{l}\text { 4. Berorientasi } \\
\text { pada tindakan }\end{array}$ & $\begin{array}{l}\text { Mengambil inisiatif untuk bertindak, dan bukan menunggu, sebe- } \\
\text { lum sebuah kejadian yang tidak dikehendaki terjadi. }\end{array}$ \\
\hline 5. Kepemimpinan & $\begin{array}{l}\text { Sikap dan perilaku seseorang yang selalu terbuka terhadap saran } \\
\text { dan kritik, mudah bergaul, bekerjasama, dan mengarahkan orang } \\
\text { lain. }\end{array}$ \\
\hline 6. Kerja Keras & $\begin{array}{l}\text { Perilaku yang menunjukkan upaya sungguh-sungguh dalam meny- } \\
\text { elesaikan tugas dan mengatasi berbagai habatan }\end{array}$ \\
\hline 7. Jujur & $\begin{array}{l}\text { Perilaku yang didasarkan pada upaya menjadikan dirinya sebagai } \\
\text { orang yang selalu dapat dipercaya dalam perkataan, tindakan, dan } \\
\text { pekerjaan. }\end{array}$ \\
\hline 8. Disiplin & $\begin{array}{l}\text { Tindakan yang menunjukkan perilaku tertib dan patuh pada berb- } \\
\text { agai ketentuan dan peraturan. }\end{array}$ \\
\hline 9. Inovatif & $\begin{array}{l}\text { Kemampuan untuk menerapkan kreativitas dalam rangka mem- } \\
\text { ecahkan persoalan-persoalan dan peluang untuk meningkatkan dan } \\
\text { memperkaya kehidupan }\end{array}$ \\
\hline $\begin{array}{l}\text { 10. Tanggung- } \\
\text { jawab }\end{array}$ & $\begin{array}{l}\text { Sikap dan perilaku seseorang yang mau dan mampu melaksanakan } \\
\text { tugas dan kewajibannya }\end{array}$ \\
\hline 11. Kerja sama & $\begin{array}{l}\text { Perilaku yang didasarkan pada upaya menjadikan dirinya mampu } \\
\text { menjalin hubungan dengan orang lain dalam melaksanakan tinda- } \\
\text { kan, dan pekerjaan. }\end{array}$ \\
\hline $\begin{array}{l}\text { 12. Pantang me- } \\
\text { nyerah (ulet) }\end{array}$ & $\begin{array}{l}\text { Sikap dan perilaku seseorang yang tidak mudah menyerah untuk } \\
\text { mencapai suatu tujuan dengan berbagai alternative }\end{array}$ \\
\hline 13. Komitmen & $\begin{array}{l}\text { Kesepakatan mengenai sesuatu hal yang dibuat oleh seseorang, } \\
\text { baik terhadap dirinya sendiri maupun orang lain. }\end{array}$ \\
\hline 14. Realistis & $\begin{array}{l}\text { Kemampuan menggunakan fakta/realita sebagai landasan berpikir } \\
\text { yang rasionil dalam setiap pengambilan keputusan maupun tinda- } \\
\text { kan/perbuatannya. }\end{array}$ \\
\hline $\begin{array}{l}\text { 15. Rasa ingin } \\
\text { tahu }\end{array}$ & $\begin{array}{l}\text { Sikap dan tindakan yang selalu berupaya untuk mengetahui se- } \\
\text { cara mendalam dan luas dari apa yang yang dipelajari, dilihat, dan } \\
\text { didengar }\end{array}$ \\
\hline 16. Komunikatif & $\begin{array}{l}\text { Tindakan yang memperlihatkan rasa senang berbicara, bergaul, dan } \\
\text { bekerjasama dengan orang lain }\end{array}$ \\
\hline $\begin{array}{l}\text { 17. Motivasi kuat } \\
\text { untuk sukses }\end{array}$ & Sikap dan tindakan selalu mencari solus \\
\hline
\end{tabular}


berperan untuk mengubah manusia menjadi manusia yang memiliki karakter dan atau perilaku wirausaha. Untuk mencapai hal tersebut bekal apa yang perlu diberikan kepada siswa agar memiliki karakter dan atau perilaku wirausaha yang tangguh, sehingga nantinya akan dapat menjadi manusia yang jika bekerja di kantor akan akan menjadi tenaga kerja yang mandiri kerja dan jika tidak bekerja di kantor akan menjadi manusia yang mampu menciptakan lapangan perkerjaan minimal bagi dirinya sendiri.

Nilai-nilai yang dikembangkan dalam pendidikan kewirausahaan menurut Kemendiknas adalah pengembangan nilai-nilai dari ciri-ciri seorang wirausaha. Implementasi pendidikan kewirausahaan di SMK dipilih beberapa nilai-nilai kewirausahaan yang dianggap paling pokok dan sesuai dengan tingkat perkembangan peserta didik sebanyak 17 (tujuh belas) nilai. Beberapa nilai-nilai kewirausahaan beserta diskripsinya yang akan diintegrasikan melalui pendidikan kewirausahaan seperti yang disajikan pada tabel 1 .

Implementasi dari 17 (tujuh belas) nilai pokok kewirausahaan tersebut di atas tidak serta merta secara langsung dilaksanakan sekaligus oleh satuan pendidikan, namun dilakukan secara bertahap. Tahap pertama implementasi nilai-nilai kewirausahaan diambil 6 (enam) nilai pokok, yaitu : mandiri, kreatif, berani mengambil resiko, berorientasi pada tindakan, kepemimpinan, dan kerja keras.

Latar belakang seorang wirausahawan dalam beberapa penelitian mempunyai kontribusi terhadap kepribadian seorang wirausahawan. Teori pembelajaran sosial menunjukkan bagaimana seseorang belajar dari orang lain dan sangat terkait dengan teori perilaku. Ide inti dari teori pembelajaran sosial adalah bahwa perilaku merupakan hasil dari interaksi situasi dan orang. Hal Ini merupakan menggabungkan prinsip-prinsip pengkondisian klasik dan operan dengan basis kognitif disposisional penentu perilaku seseorang.

Albert Bandura, di Stanford University, telah mengembangkan sistem pemikiran yang paling rumit pada imitasi, identifikasi, atau permodelan konsep pengajaran. Konsep ini diberi nama sistem pembelajaran sosial, Bandura memandang teori penguatan pengkondisian instrumental, seperti halnya Skinner, karena mampu menjelaskan kontrol tanggapan yang sesuai dengan apa yang dipelajari oleh pembelajar sebelumnya (Knowles dkk.,2005:103).

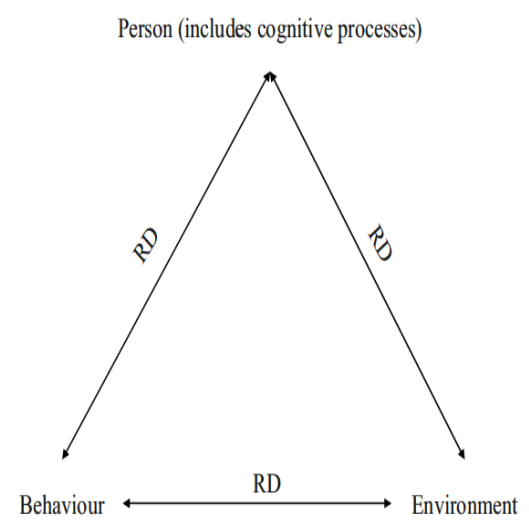

$\mathrm{RD}=$ reciprocal determinism

\section{Gambar 1. Model Pembelajaran Sosial}


Gage menyatakan bahwa "belajar melalui imitasi tampaknya sangat tepat pada bidang-bidang yang memiliki struktur kognitif kecil" (1972:47). Pengamatan ini tampaknya dibuktikan oleh kenyataan bahwa pembelajaran sosial telah diterapkan terutama untuk modifikasi perilaku dalam pengaturan terapeutik untuk memperbaiki perilaku menyimpang atau antisosial, demikian halnya untuk aplikasi seperti pendidikan positif sebagai pengembangan sikap, keyakinan, dan keterampilan kinerja juga dibuktikan (Bandura, 1969:599-624).

Dengan kognisi sebagai dasar fundamental, teori pembelajaran sosial melihat seseorang dalam sebuah keadaan timbal balik deterministik interaktif dengan lingkungan dan perilaku seperti disajikan dalam gambar 1. Seperti setiap aspek pengaruh lain, lingkungan yang sebenarnya dapat berbeda dalam persepsi individu satu dengan individu lain karena faktor kognisi.

Teori pembelajaran sosial berkontribusi untuk menjelaskan bagaimana seorang individu mempunyai perilaku kewirausahaan. Perkembangan perilaku kewirausahaan dapat terjadi ketika seorang individu mengamati dan menilai keterlibatanya dalam perilaku yang berbeda yang mendapatkan penguatan positif. Jika potensi penguatan dihargai, ia akan mencoba untuk meniru perilaku tersebut dengan penguatan yang sama. Penjelasan ini menunjukkan bagaimana perilaku kewirausahaan berkembang.

Teori pembelajaran sosial membantu untuk mengidentifikasi dan memahami faktor-faktor fundamental penentu dari perilaku dan aktivitas kewirausahaan. Hal ini menyangkut pertanyaan-pertanyaan "apa yang mempengaruhi orang untuk mengembangkan perilaku kewirausahaan" dan "mengapa orang memilih kewirausahaan sebagai pilihan". Individu memandang dan menilai perilaku di lingkungan sosial mereka dan menggunakan hal ini untuk memeriksa apakah hasilnya menawarkan penguatan dalam penyesuaian dan pengembangan hirarki kebiasaan tertentu dari kepribadian masing-masing. Hal ini membentuk keyakinan, sikap dan kemauan seorang wirausahawan.

Pada saat yang sama, teori pembelajaran sosial menggambarkan bagaimana pilihan untuk menjadi wirausahawan dipengaruhi oleh pengamatan dan model evaluasi pilihan karir. Teori pembelajaran sosial menjelaskan bagaimana perilaku kewirausahaan dan pilihan karir dapat dipelajari dan dipengaruhi. Kegiatan wirausaha ternyata tidak semata-mata warisan maupun bawaan, tetapi merupakan sesuatu yang dapat dipengaruhi dan diajarkan. Dalam konteks ini upaya dan pendekatan lembaga pendidikan termasuk sekolah sebagai semacam organisasi dapat dikaji berkaitan dengan pengembangan kewirausahaan, kemauan dan perilaku di kalangan siswanya. Terutama peran pendidikan kewirausahaan sebagai media untuk membentuk jiwa dan kemauan berwirausaha. Lembaga pendidikan termasuk universitas pada umumnya adalah media masyarakat untuk mentransfer dan menerapkan konsep-konsep teoritis dan empirik. Proses pendidikan merepresentasikan dan mengaplikasikan suatu bentuk organisasi sosial.

Bagian dari teori pembelajaran sosial yang paling relevan dalam hal ini adalah konsep Pembelajaran Observasional. Pembelajaran observasional adalah pembelajaran yang melibatkan bagaimana seseorang memperoleh keterampilan, strategi, dan keyakinan dengan mengamati orang lain. Belajar observasional melibatkan imitasi namun tidak terbatas hanya itu (Santrock, 2011:236). Apa yang dipelajari biasanya bukan salinan tepat dari apa yang dimodelkan melainkan bentuk umum atau strategi yang sering diterapkan pengamat dengan cara-cara kreatif. Kapasitas untuk belajar pola perilaku dengan observasi mementahkan pendapat trial-and-error learning. Dalam banyak kasus, pembelajaran ob- 
servasional membutuhkan waktu lebih singkat dari pada operant conditioning.

Penelitian tentang pengembangan model pembelajaran internalisasi nilai-nilai kewirausahaan pada SMK di kota Malang dilakukan oleh Agung Winarno (2009:124-131). Penelitian ini dengan menghasilkan beberapa kesimpulan diantaranya adalah kecenderungan sikap atau nilai-nilai kewirausahaan yang dimiliki siswa berdasarkan hasil tes menunjukkan angka yang relatif belum optimal hal ini mengindikasikan bahwa sikap kewirausahaan siswa belum terbentuk dengan baik. Model pembelajaran yang digunakan guru, hasil penelitian juga menunjukkan minimnya variasi dan tidak banyak yang menyentuh penggunaan model yang mengarah pada pembentukan nilai-nilai (afeksi).

Penelitian yang dilakukan oleh Adeyemi (2009:313-332) tentang keterkaitan atau hubungan faktor-faktor guru dengan pencapaian belajar siswa pada pelajaran sosial di Nigeria. Faktor-faktor yang terkait dengan guru ini diantaranya adalah tingkat penilaian guru dalam gaya menilai, gaya penilaian guru, serta karakteristik personal guru yaitu kualifikasi, pengalaman mengajar dan gaya mengajar. Penelitian inin menghasilkan kesimpulan bahwa faktor guru terbukti secara meyakinkan mempunyai keterkaitan kuat dengan pencapaian belajar siswa. Andrew J. Wayne dan Peter Youngs (2003:89-122) melakukan penelitian tentang karaktersitik guru dan tingkat pencapaian siswa. Temuan dari penelitian ini adalah adanya keterkaitan antara karakteristik guru dengan tingkat pencapaian belajar siswa. Penelitian yang dilakukan oleh Will Dobbie (2011) di Amerika juga menghasilkan kesimpulan yang serupa. Sedangkan penelitian yang dilakukan oleh Douglas N. Harris dan Tim R. Sass (2006) menghasilkan kesimpulan bahwa profesionalisme guru mempunyai hubungan yang positif terhadap pencapaian belajar siswa. Kesimpulan selanjutnya menunjukkan bahwa pengalaman guru juga berpengaruh positif pada efektifitas pembelajaran.

Penelitian yang dilakukan oleh Endang Koesmiyati (2007) berkesimpulan bahwa meskipun terdapat beberapa faktor yang saling mempengaruhi terbentuknya kepribadian siswa, tetapi dijumpai pula faktor-faktor yang mendorong terbentuknya kepribadian siswa, antara lain adanya guru yang berperan aktif dalam membentuk kepribadian siswa di sekolah. Sedangkan penelitian yang dilakukan oleh Pihie dan Sani (2009) di Malaysia menghasilkan salah satu kesimpulan yaitu model pembelajaran berpusat pada siswa dengan pendekatan pengarahan kewirausahaan memungkinkan siswa untuk memiliki pola pikir kewirausahaan yang positif. Selanjutnya Acikgoz (2005:111) menyimpulkan bahwa karakteristik guru mempunyai pengaruh penting pada pembentukan karakter siswanya, hal ini diperkuat oleh Saghafi dan Shatalebi (2012:58) serta Lumpkin (2008:49) yang menyatakan bahwa proses pendidikan karakter pada dasarnya berawal dari guru dan berakhir pada siswa. Dengan demikian peran guru menjadi sangat penting dan tidak dapat dipisahkan dalam proses pendidikan karakter.

Howard S Rasheed dan Barbara Y Rasheed (2003:261-277) juga menyimpulkan bahwa pendidikan kewirausahaan dapat mempengaruhi karakteristik kewirausahaan umum di kalangan pelajar tingkat menengah. Secara khusus, siswa dengan pelatihan kewirausahaan secara keseluruhan memiliki karakteristik kewirausahaan yang lebih besar, motivasi berprestasi yang lebih tinggi, kontrol pribadi lebih baik, dan harga diri mempunyai lebih besar daripada kelompok pembanding.

Dari beberapa penelitian diatas dapat ditarik asumsi bahwa pendidikan kewirausahaan dapat mempengaruhi karakter kewirausahaan siswa SMK Negeri di Surabaya. Asumsi ini dilandasi bahwa mata pelajaran kewirausahaan telah diajarkan pada siswa 
SMK Negeri di Surabaya. Secara khusus penelitian ini ingin melihat kontribusi Kredibilitas dan Otentisitas guru yang mengajar mata pelajaran kewirausahaan terhadap karakter kewirausahaan siswa SMK Negeri di Surabaya

Melihat berbagai fenomena diatas, penelitian ini menjadi penting untuk dilakukan terutama dalam pembelajaran kewirausahaan di SMKN di Surabaya sebagai upaya untuk Memperoleh pembuktian dan penjelasan tentang Menghasilkan pembuktian besaran pengaruh kredibilitas dan otentisitas guru terhadap karakter kewirausahaan siswa SMK Negeri di Surabaya.

Berlandaskan pendahuluan yang telah diuraikan sebelumnya, maka dapat dirumuskan beberapa hipotesis sebagai berikut:

1. Kredibilitas guru berpengaruh positif terhadap karakter kewirausahaan siswa SMK Negeri di Surabaya.

2. Otentisitas guru berpengaruh positif terhadap karakter kewirausahaan siswa SMK Negeri di Surabaya.

3. Kredibilitas dan otentisitas guru berpengaruh positif terhadap karakter kewirausahaan siswa SMK Negeri di Surabaya secara simultan.

\section{METODE PENELITIAN}

Metode yang digunakan dalam penelitian ini adalah metode kuantitatif, karena penelitian ini didasarkan pada data kuantitif (VanderStoep dan Johnston, 2009:7; Suliyanto, 2006:12). Penelitian ini termasuk dalam kategori penelitian hubungan kausal (causal relationship) karena bermaksud menjelaskan hubungan kausal antara variabel-variabel melalui pengujian hipotesis (Bordens dan Abbott, 2011:103).

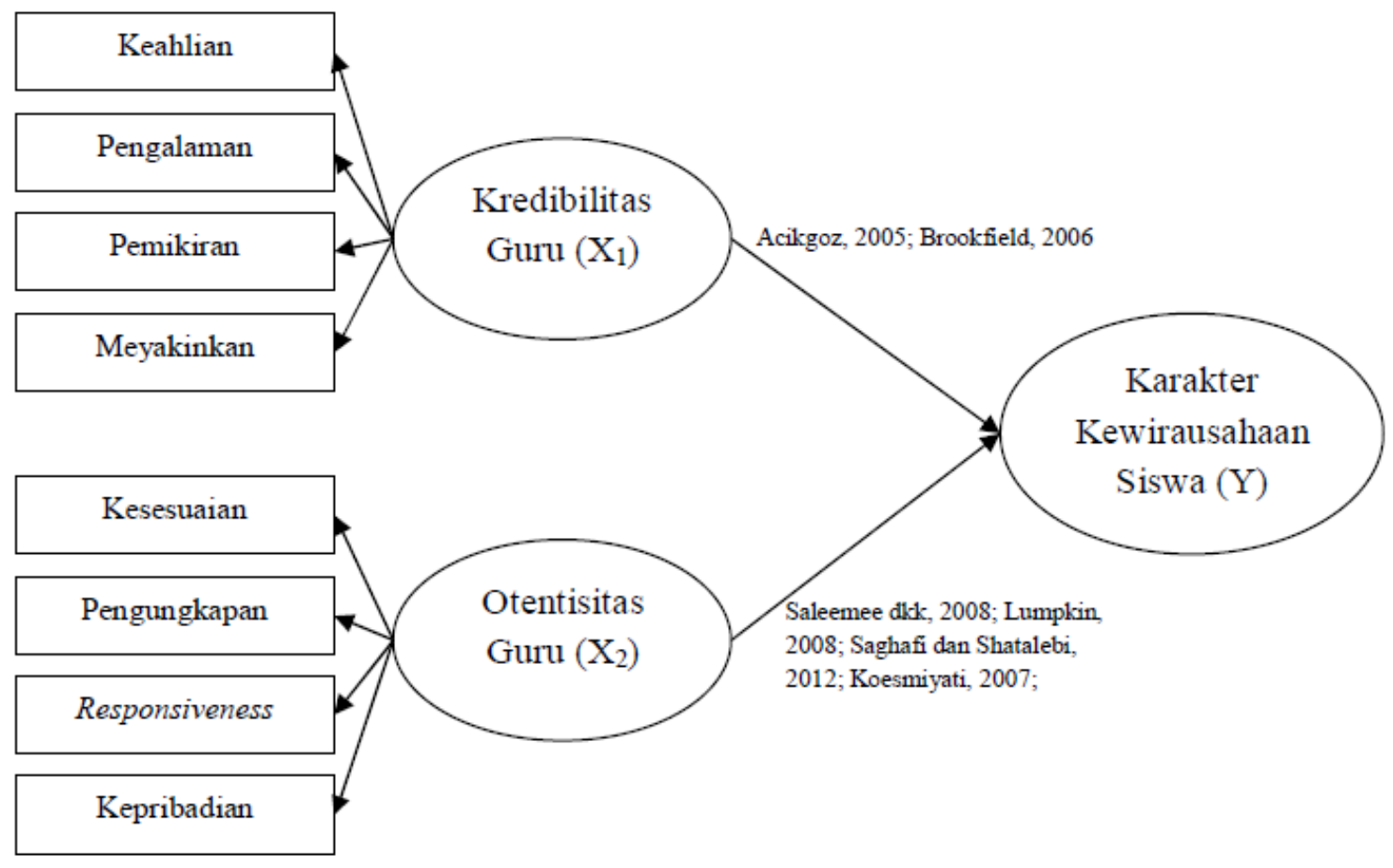

Gambar 2. Model Penelitian 
Pengujian pengaruh variabel kredibilitas dan otentisitas guru kewirausahaan terhadap karakter kewirausahaan siswa SMK Negeri di Surabaya menggunakan analisis structural equation model (SEM). Analisis SEM merupakan generasi kedua teknik analisis multivariat yang memungkinkan peneliti untuk menguji hubungan antara variabel yang kompleks baik recursive maupun nonrecursive untuk memperoleh gambaran menyeluruh mengenai suatu model. Variabel eksogen dalam penelitian ini adalah variabel kredibilitas dan otentisitas guru kewirausahaan. Sedangkan variabel endogennya adalah variabel karakter kewirausahaan siswa. model penelitian yang digunakan diilustrasikan pada gambar 2 .

Populasi sasaran dalam penelitian ini adalah seluruh siswa kelas XII SMK Negeri di Surabaya yang berjumlah kurang lebih 7.684 siswa. Unit penelitian/analisis dalam penelitian ini adalah individu sebagai siswa. Sedangkan unit pengamatan/subyek penelitian ini adalah siswa SMK Negeri di Surabaya yang telah selesai mengikuti mata pelajaran kewirausahaan. Ukuran sampel yang disarankan dalam menggunakan analisis SEM dengan menggunakan metode estimasi Maximum Likelihood yaitu sebesar 100-200, sampel besar akan mengakibatkan indeks goodnes of fit menjadi sangat sensitif (Ghozali dan Fuad, 2005:36). Dengan demikian besaran sampel yang digunakan dalam penelitian ini adalah 200 siswa responden.

\section{Hasil Penelitian}

\section{HASIL PENELITIAN DAN PEMBAHASAN}

Data hasil penelitian menunjukkan penilaian kredibilitas dan otentisitas guru kewirausahaan di mata siswanya menunjukkan nilai yang belum optimal. Skor rata-rata penilaian siswa terhadap kredibilitas guru kewirausahaan di SMKN adalah 3,3 dengan skala pengukuran 1 sampai 5. Skor penilaian siswa terhadap otentisitas guru kewirausahaan mereka juga tidak jauh berbeda yaitu sebesar 3,2. Berdasarkan pada data penilaian siswa ini dapat dikatakan bahwa guru kewirausahaan SMKN di Surabaya masih belum kredibel dan otentik.

Hal ini menunjukkan bahwa jenjang pendidikan dan sertifikasi tidak menjamin kredibilitas dan otentisitas guru. Dengan demikian peningkatan jenjang pendidikan dan program sertifikasi saja tidak cukup dalam meningkatkan kualitas guru. Karena kualitas guru merupakan salah satu faktor kunci dalam meningkatkan kualitas pembelajaran di sekolah maka perlu dilakukan upaya lebih lanjut yang lebih komprehensif. Fenomena ini juga menjadi bukti bahwa proses pembelajaran guru di Indonesia juga masih perlu dikaji, karena terbukti belum mampu menghasilkan output yang berkualitas.

Hasil penelitian pada karakter kewirausahaan siswa SMKN di Surabaya menunjukan nilai yang juga masih belum memuaskan, dimana dari skala pengukuran 1 sampai 5 hanya diperoleh rata-rata skor sebesar 3,9 dari tiap-tiap indikator. Hal ini sejalan dengan tingkat kredibilitas dan otentisitas guru yang masih rendah.

Untuk mendapatkan kriteria model yang dapat diterima, dilakukan pengukuran goodness-of-fit model. Hasil pengukuran goodness-of-fit model pada tabel 2 mengindikasi bahwa model yang diajukan dalam penelitian ini dapat diterima. Hal ini dikarenakan nilai Chi-Square yang menunjukkan nilai sebesar 1354,551 dengan probabilitas 0,000 menjelaskan bahwa overall fit dari model penelitian ini dapat dikatakan moderat. Namun demikian, analis masih dapat dilakukan, sebab ukuran suatu model tidak hanya dilihat dari nilali probabilitas tetapi juga dilihat dari kriteria fit yang lain yaitu GFI, AGFI, CFI, TLI, dan RMSEA (Selnes, 1998; Ghozali, 2005). 
Tabel 2. Hasil Goodness-of-Fit Model Struktural

\begin{tabular}{|l|c|c|c|}
\hline $\begin{array}{c}\text { Goodness-of-Fit } \\
\text { Indeks }\end{array}$ & $\begin{array}{c}\text { Nilai yang } \\
\text { diharapkan }\end{array}$ & Hasil & Evaluasi \\
\hline Chi-Square & Diharapkan kecil & 1354.55 & Moderat \\
\hline Probabilitas & $\geq 0,05$ & 0,000 & Moderat \\
\hline GFI & $\geq 0,90$ & 0,756 & Moderat \\
\hline AGFI & $\geq 0,90$ & 0,725 & Moderat \\
\hline CFI & $\geq 0,90$ & 0,906 & Baik \\
\hline RMSEA & $\leq 0,08$ & 0,060 & Baik \\
\hline
\end{tabular}

Sumber: Hasil Pengolahan Data Penelitian tahun 2012

Goodness-of-Fit Index (GFI) yang menunjukkan tingkat kesesuaian model secara keseluruhan yang dihitung dari residual kuadrat dari model yang diprediksi dibandingkan data yang sebenarnya. Nilai yang mendekati 1 mengisyaratkan model yang diuji memiliki kesesuaian yang baik. Dengan tingkat penerimaan yang direkomendasikan $>0,9$ dapat disimpulkan bahwa model penelitian ini memiliki tingkat kesesuaian yang marginal dengan nilai GFI sebesar 0,756 .

Adjusted Goodness-of-Fit Index (AGFI) adalah GFI yang disesuaikan dengan rasio antara degree of freedom dari model yang diusulkan dan degree of freedom dari null model. Nilai AGFI dalam model ini adalah 0,725 menunjukkan bahwa model dinilai cukup.

Comparative Fit Index (CFI) adalah indeks kesesuaian incremental yang membandingkan model yang diuji dengan null model. Besaran indeks ini dalam rentang 0 sampai 1 dan nilai yang mendekati 1 mengindikasikan model memiliki tingkat kesesuaian yang baik. Indeks ini sangat dianjurkan untuk dipakai karena indeks ini relatif tidak sensitif dengan besarnya sampel dan kurang dipengaruhi oleh kerumitan model. Dengan memperhatikan nilai yang direkomendasikan yaitu $>0,9$; maka nilai CFI sebesar 0,906 menunjukkan bahwa model ini memiliki kesesuaian yang baik.

The Root Mean Square Error of Approximation (RMSEA) adalah indeks yang digunakan untuk mengkompensasi nilai Chi-Square dalam sampel yang besar. Nilai penerimaan yang direkomendasikan $<0,08$; nilai RMSEA model sebesar 0,060 menunjukkan tingkat kesesuaian yang baik. Dengan demikian secara keseluruhan dapat dikatakan bahwa model mempunyai goodness-of-fit yang baik sehingga dapat digunakan sebagai model prediksian yang akurat. Jadi dapat disimpulkan bahwa variabel kredibilitas dan otentisitas guru kewirausahaan secara simultan mempunyai pengaruh yang signifikan terhadap karakter kewirausahaan siswa SMKN di Surabaya.

Berikutnya adalah penjelasan dari hasil pengujian hipotesis dengan menganalisis tingkat signifikansi standardized structural (path) coefficients dari setiap hipotesis terutama pada kesesuaian arah hubungan path dengan arah hubungan yang telah dihipotesiskan sebelumnya. Jika arah hubungan sesuai dengan yang dihipotesiskan dan nilai critical ratio juga memenuhi persyaratan maka dapat dikatakan bahwa hipotesis yang diuji terbukti.

Pengujian hipotesis "Kredibilitas guru kewirausahaan berpengaruh positif terhadap karakter kewirausahaan siswa SMKN di Surabaya" dilakukan dengan menggunakan Uji t. Hasil perhitungan koefisien pengaruh dan statistik uji t dapat dilihat pada Tabel 3. Diketahui nilai thitung untuk koefisien jalur variabel X1 ke Y sebesar 1,23 dan nilai t tabel adalah 1,658, maka ( diterima). Jadi dapat disimpulkan bahwa kredibilitas guru kewirausahaan (X1) tidak berpengaruh secara signifikan terhadap karakter kewirausahaan siswa (Y). 
Tabel 3. Uji Hipotesis Pengaruh Secara Parsial

\begin{tabular}{|c|c|c|c|c|c|c|}
\hline No & Hipotesis & $\begin{array}{c}\text { Kriteria } \\
\text { Uji }\end{array}$ & $t_{\text {hitung }}$ & $t_{\text {tabel }}$ & $\begin{array}{c}\text { Hasil } \\
\text { Statistik }\end{array}$ & Kesimpulan \\
\hline 1 & $\begin{array}{l}\text { Kredibilitas Guru } \\
\text { Kewirausahaan }\left(\mathrm{X}_{1}\right) \\
\text { berpengaruh positif } \\
\text { terhadap karakter } \\
\text { kewirausahaan siswa (Y) }\end{array}$ & \begin{tabular}{c|}
$\mathrm{H}_{0}$ \\
ditolak, \\
jika \\
$t_{\text {hitung }} \geq t_{\text {tab }}$ \\
tidak
\end{tabular} & 1,23 & 1,658 & $\begin{array}{l}\mathrm{H}_{0} \\
\text { diterima }\end{array}$ & $\begin{array}{l}\text { Tidak terdapat pengaruh } \\
\text { Kredibilitas Guru } \\
\text { Kewirausahaan }\left(\mathrm{X}_{1}\right) \\
\text { terhadap karakter } \\
\text { kewirausahaan siswa }(\mathrm{Y})\end{array}$ \\
\hline 2 & $\begin{array}{l}\text { Otentisitas Guru } \\
\text { Kewirausahaan }\left(\mathrm{X}_{2}\right) \\
\text { berpengaruh positif } \\
\text { terhadap karakter } \\
\text { kewirausahaan siswa (Y) }\end{array}$ & $\begin{array}{c}\text { menolak, } \\
\mathrm{H}_{0} \text { jika } \\
t_{\text {zaturg }}<t_{\text {tasee }}\end{array}$ & $-0,73$ & 1,658 & $\begin{array}{l}\mathrm{H}_{0} \\
\text { diterima }\end{array}$ & $\begin{array}{l}\text { Tidak terdapat pengaruh } \\
\text { Otentisitas Guru } \\
\text { Kewirausahaan }\left(\mathrm{X}_{2}\right) \\
\text { terhadap karakter } \\
\text { kewirausahaan siswa }(\mathrm{Y})\end{array}$ \\
\hline
\end{tabular}

Sumber: Hasil Pengolahan Data Penelitian tahun 2012

Besaran koefisien jalur antara variabel kredibilitas guru kewirausahaan terhadap karakter kewirausahaan siswa SMKN sama dengan 0,58. Dengan demikian variabel kredibilitas guru kewirausahaan secara parsial tidak mempunyai pengaruh yang berarti terhadap karakter kewirausahaan siswa SMKN di surabaya. Besar pengaruh kredibilitas guru kewirausahaan terhadap karakter kewirausahaan siswa SMKN secara parsial sebesar $34 \%(0,582)$ atau namun karena uji signifikansi menolak adanya pengaruh tersebut makan dapat dikatakan bahwa pengaruh variabel kredibilitas guru kewirausahaan terhadap karakter kewirausahaan siswa SMKN di Surabaya adalah lemah.

Pengujian hipotesis ke-dua yaitu hipotesis "Otentisitas guru kewirausahaan berpengaruh positif terhadap karakter kewirausahaan siswa SMKN di Surabaya" dilakukan dengan menggunakan Uji t. Dari hasil perhitungan diketahui nilai t hitung untuk koefisien jalur variabel $\mathrm{X} 2 \mathrm{ke}$ Y sebesar -0,73 dan nilai t tabel adalah 1,658, maka ( diterima). Jadi dapat disimpulkan bahwa otentisitas guru kewirausahaan (X1) tidak berpengaruh secara signifikan terhadap karakter kewirausahaan siswa (Y).

Besaran koefisien jalur antara variabel otentisitas guru kewirausahaan terhadap karakter kewirausahaan siswa SMKN sama dengan -0,34. Dengan demikian variabel kredibilitas guru kewirausahaan secara parsial tidak mempunyai pengaruh yang berarti terhadap karakter kewirausahaan siswa SMKN di surabaya. Besar pengaruh kredibilitas guru kewirausahaan terhadap karakter kewirausahaan siswa SMKN secara parsial sebesar 12\% $(-0,342)$ atau namun karena uji signifikansi menolak adanya pengaruh tersebut makan dapat dikatakan bahwa pengaruh variabel otentisitas guru kewirausahaan terhadap karakter kewirausahaan siswa SMKN di Surabaya adalah sangat lemah.

\section{Pembahasan}

Pada hasil uji hipotesis menyatakan bahwa ada pengaruh yang berarti dari kredibilitas dan otentisitas guru kewirausahaan terhadap karakter kewirausahaan siswa SMKN di Surabaya secara simultan. Dimana kedua variabel eksogen ini mempengaruhi variabel endogen sabagai suatu kesatuan. Dengan demikian kedua variabel ini mampu memberikan kontribusi yang berarti dalam pembentukan karakter kewirausahaan siswa SMKN di Surabaya.

Hasil penelitian ini sesuai dengan kesimpulan hasil penelitian yang dilakukan oleh Acikgoz (2005:111). Dimana dalam penelitian tersebut menyimpulkan bahwa karakteris- 
tik guru mempunyai pengaruh penting pada pembentukan karakter siswanya. Kesimpulan yang diungkapkan Saghafi dan Shatalebi (2012:58) serta Lumpkin (2008:49) yang menyatakan bahwa proses pendidikan karakter pada dasarnya berawal dari guru dan berakhir pada siswa, sudah terbukti sesuai dengan proses pembelajaran kewirausahaan pada SMKN di Surabaya. Hal ini menguatkan peran guru dalam pembentukan karakter kewirausahaan mempunyai kontribusi yang signifikan. Dimana Kementerian Pendidikan Nasional memandang guru adalah agen perubahan ditingkat sekolah yang diharapkan mampu menanamkan karakter dan perilaku wirausaha bagi jajaran dan peserta didiknya (Kemendiknas, 2010:22). Dalam konteks pembelajaran kewirausahaan, guru diharapkan mampu memberikan keteladanan terhadap penanaman nilai-nilai kewirausahaan kepada peserta didik terutama enam karakter pokok kewirausahaan.

Pada pengujian hipotesis bahwa adanya pengaruh positif dari kredibilitas guru kewirausahaan terhadap karakter kewirausahaan siswa SMKN di surabaya secara parsial menunjukkan hasil yang tidak signifikan. Begitu pula pengujian hipotesis pengaruh otentisitas guru kewirausahaan terhadap karakter kewirausahaan siswa SMKN di surabaya menunjukkan hasil yang sama. Dalam pengujian ini kedua variabel tersebut tidak dianggap sebagai satu kesatuan, melainkan suatu dimensi yang berbeda dan berdiri sendiri. Pada pengujian secara parsial inilah kedua variabel tersebut tidak terbukti secara signifikan mempengaruhi karakter kewirausahaan siswa.

Walaupun secara parsial kedua variabel tersebut tidak memberikan kontribusi pada pembelajaran karakter kewirausahaan siswa, namun sebagai satu kesatuan kedua variabel tersebut terbukti secara meyakinkan mempunyai pengaruh positif pada karakter kewirausahaan siswa. Pembuktian ini sangat sesuai dengan apa yang dikatakan Brookfield (2006:55-56) bahwa dalam pembelajaran yang efektif guru harus mempunyai kredibilitas dan otentisitas yang baik. Ketiadaan salah satunya tidak akan menjamin proses pembelajaran menjadi berkualitas.

Mengacu pada data penelitian yang diperoleh bahwa para siswa SMKN di Surabaya belum menganggap guru mereka kredibel dan ontentik dalam melakukan proses pembelajaran di kelas, maka keterkaitan fenomena ini dengan hasil analisis statistik pada bab 4 yang menyatakan bahwa tidak ada pengaruh nyata antara kredibilitas maupun otentisitas guru kewirausahaan terhadap karakter kewirausahaan siswa SMKN di Surabaya menjadi layak untuk dikaji.

Sejak suasana kelas pembelajaran (classroom learning climate) menjadi fenomena interaksi dalam proses pembelajaran maka guru diharapkan mampu membangun suasana kelas yang positif. Dalam suasana pembelajaran di kelas yang positif akan meningkatkan efektifitas pembelajaran. Guru dengan kredibilitas yang rendah akan sangat kesulitan dalam membangun iklim pembelajaran yang baik, dengan demikian walaupun guru kewirausahaan sudah memiliki jenjang pendidikan yang cukup namun belum mempunyai kredibilitas yang cukup dalam membangun proses pembelajaran yang efektif.

Dalam konteks pembelajaran karakter kewirausahaan kemampuan guru untuk merancang pembelajaran yang terintegrasi nilai-nilai kewirausahaan masih patut untuk dipertanyakan. Pengakuan siswa dalam penelitian ini menunjukkan seluruh indikator kredibilitas guru mempunyai nilai yang kurang bagus. Lumpkins (2008:48) mengatakan bahwa ketika guru mempunyai integritas dalam proses pembelajaran maka akan terjadi kecenderungan peserta didik untuk mengadopsi karakter gurunya. Guru dalam hal ini akan menjadi model bagi siswa bagaimana berprilaku adil, bertanggung jawab, jujur, per- 
hatian pada sesama dan lain-lain. Guru dengan kredibilitas yang rendah akan kesulitan membangun proses pembelajaran yang berkualitas, serta tidak mampu menjadi contoh yang baik dalam proses pembentukan karakter kewirausahaan siswa.

Dengan demikian apa yang telah menjadi program Kementrian Pendidikan Nasional dalam upaya meningkatkan kualitas proses pembelajaran kewirausahaan di sekolah perlu didukung oleh semua pihak yang berkompeten, agar guru mampu memberikan keteladanan terhadap penanaman nilai-nilai kewirausahaan kepada peserta didik terutama enam nilai pokok kewirausahaan, mampu merancang pembelajaran yang terintegrasi nilai-nilai kewirausahaan, mampu memahami konsep-konsep kewirausahaan, serta memiliki keterampilan atau skill berwirausaha.

\section{KESIMPULAN}

Hasil analisis dan pembahasan tentang pengaruh variabel kredibilitas dan otentisitas guru kewirausahaan terhadap karakter kewirausahaan siswa SMKN di Surabaya dengan metode penelitian kuantitatif menggunakan model Struktural Equation Modeling (SEM) diperoleh beberapa simpulan. Pertama, pengaruh variabel kredibilitas guru kewirausahaan terhadap karakter kewirausahaan siswa SMKN di Surabaya tidak terbukti signifikan. Besaran pengaruh variabel ini pada pembentukan karakter kewirausahaan siswa secara parsial menunjukkan nilai yang sangat kecil. Hasil ini membuktikan fenomena bahwa guru kewirausahaan belum memberikan kontribusi yang berarti dalam pembentukan karakter kewirausahaan siswa SMKN di Surabaya.

Simpulan ke-dua, pengaruh variabel otentisitas guru kewirausahaan terhadap karakter kewirausahaan siswa SMKN di Surabaya juga tidak menunjukkan simpulan yang signifikan. Besaran pengaruh variabel ini terhadap karakter kewirausahaan siswa secara parsial sangat kecil. Harapan bahwa guru dapat menjadi teladan dalam proses pembelajaran karakter kewirausahaan siswa di SMK belum dapat dibuktikan dalam penelitian ini. Ketiga, pengaruh variabel kredibilitas dan otentisitas guru kewirausahaan terhadap karakter kewirausahaan siswa SMKN di Surabaya secara simultan menunjukkan simpulan yang meyakinkan. Hasil ini selaras dengan beberapa penelitian sebelumnya serta sesuai dengan konsep bahwa dalam pembelajaran yang efektif guru harus mempunyai kredibilitas dan otentisitas yang baik, ketiadaan salah satunya akan mengakibatkan ketidakberhasilan proses pembelajaran karakter kewirausahaan dalam mencapai tujuan pembelajaran.

Mengingat adanya pengaruh simultan antara variabel kredibilitas dan otentisitas guru kewirausahaan terhadap karakter kewirausahaan siswa SMKN di Surabaya serta masih belum optimalnya tingkat kredibilitas dan otentisitas guru kewirausahaan maka dalam upaya untuk meningkatkan karakter kewirausahaan siswa SMKN di surabaya perlu adanya program peningkatan kualitas guru kewirausahaan. Peningkatan kualitas guru ini harus mencakup aspek kredibilitas dan otentisitas guru.

Berdasarkan hasil penelitian ini yang mengindikasikan masih belum optimalnya tingkat kredibilitas dan otentisitas guru kewirausahaan, maka disarankan untuk melakukan studi lanjutan tentang karakteristik maupun atribut-atribut guru kewirausahaan dalam upaya mendapatkan kajian yang lebih lengkap sebagai landasan dalam peningkatan peran guru dalam pembentukan karakter siswanya.

Belum terbuktinya pengaruh positif dari variabel kredibilitas maupun otentisitas guru kewirausahaan terhadap karakter kewirausahaan siswa SMKN di surabaya secara 
parsial maka kajian-kajian lanjutan tentang kredibilitas dan otentisitas guru ini perlu dilakukan, terutama terkait dengan pengembangan model penelitian yang lebih kompleks dan komprehensif.

\section{DAFTAR RUJUKAN}

Adeyemi, Babatunde, 2010. Teacher Related Factor As Correlates of Pupils' Achievement in Social Studies in Southwestern Nigeria. Electronic Journal of Research in Educational Psychology : 2010 (313-332)

Brookfield, Stephen D. 2006. The Skillful Teacher : On Technique, Trust, And Responsiveness In The Classroom. San Francisco : John Wiley \& Sons, Inc.

Cranton, Patricia and Carusetta, Ellen. 2004. Perspectives on Authenticity in Teaching. Adult Education Quarterly, Vol. 55 No. 1, November 2004, pp.5-22.

Dobbie, Will. 2011. Teacher Characteristics and Student Achievement: Evidence from Teach For America. Harvard University.

Ghozali, Imam dan Fuad. 2005. Structural Equation Modeling : Teori, Konsep, \& Aplikasi Dengan Program Lisrel 8.54. Semarang : Badan Penerbit Universitas Diponegoro.

Ghozali, Imam. 2005. Aplikasi Analisis Multivariate dengan Program SPSS. Semarang : Badan Penerbit Universitas Diponegoro.

Koesmiyati, Endang. 2007. Kompetensi Guru Pendidikan Pancasila Kewarganegaraan (PPKn) dalam Meningkatkan Kepribadian Siswa. Likithapradnya. Tahun 10 Vol. II September 2007, pp.47-60.

Lumpkin, Angela. 2008. Teachers as Role Models Teaching Character and Moral Virtues. JOPERD, Vol. 79 No. 2, February 2008. pp. 45-49.

Rasheed, Howard S. and Rasheed, Barbara Y. 2003. Developing Entrepreneurial Characteristics In Minority Youth: The Effects Of Education And Enterprise. International Research in the Business Disciplines, Volume 4. Emerald Group Publishing Limited, pp.261-277.

Santrock, John W. 2011. Educational psychology. New York : McGraw-Hill.

Undang-Undang Republik Indonesia Nomor 14 Tahun 2005 Tentang Guru Dan Dosen.

Vander Stoep, Scott W. and Johnston, Deirdre D. 2009. Research Methods For Everyday Life: Blending Qualitative and Quantitative Approaches. San Fancisco : Jossey-Bass.

Wayne, Andrew J. and Youngs, Peter. 2003. Teacher Characteristics and Student Achievement Gains: A Review. Review of Educational Research. Vol. 73, No. 1 Spring 2003, pp. 89-122.

Winarno, Agung. 2009. Pengembangan Model Pembelajaran Internalisasi Nilai-Nilai Kewirausahaan pada Sekolah Menengah Kejuruan di Kota Malang. Jurnal Ekonomi Bisnis, Tahun 14, Nomor 2, Juli 2009 pp. 124-131 